\title{
Refinement of the Taxonomic Structure of 16SrXI and 16SrXIV Phytoplasmas of Gramineous Plants using Multilocus Sequence Typing
}

\author{
Saman Abeysinghe and Pushpa Damayanthi Abeysinghe, Department of Botany, Faculty of Science, University of Ruhuna, Matara, Sri \\ Lanka; Chamini Kanatiwela-de Silva and Preethi Udagama, Department of Zoology, Faculty of Science, University of Colombo, Colombo \\ 03, Sri Lanka; Kanjana Warawichanee, Plant Virology Section, Department of Agriculture, Chatuchak, Bangkok, 10900, Thailand; and \\ Naofel Aljafar, Praphat Kawicha, and Matt Dickinson, School of Biosciences, Sutton Bonington Campus, University of Nottingham, \\ LE12 5RD, UK
}

\begin{abstract}
Abeysinghe, S., Kanatiwela-de Silva, C., Abeysinghe, P. D., Udagama, P., Warawichanee, K., Aljafar, N., Kawicha, P., and Dickinson, M. 2016. Refinement of the taxonomic structure of 16SrXI and 16SrXIV phytoplasmas of gramineous plants using multilocus sequence typing. Plant Dis. 100:2001-2010.

Phytoplasmas that infect gramineous plants, including Napier grass stunt, sugarcane whiteleaf, sugarcane grassy shoot, and Bermuda grass whiteleaf, have been classified into two closely related groups, $16 \mathrm{SrXI}$ and $16 \mathrm{SrXIV}$, based on the $16 \mathrm{~S}$ ribosomal RNA (rRNA) gene. Subsequently, phytoplasmas associated with coconut and Areca palm in southern India and Sri Lanka have been added into the 16SrXI group. However, the $16 \mathrm{~S}$ rRNA gene gives relatively poor resolution between these phytoplasmas. In this study, a new set of universal phytoplasma primers that amplify approximately $1 \mathrm{~kb}$ of the leucyl transfer RNA synthetase (leuS) gene have been validated on a broad range of phytoplasma taxonomic groups.

These have been used along with partial sequences of the $\sec A$ gene to clarify the taxonomic classification of $16 \mathrm{SrXI}$ and $16 \mathrm{SrXIV}$ phytoplasmas. Based on this data, the sugarcane whiteleaf and grassy shoot phytoplasmas appear to be the same phytoplasma. The Napier grass stunt phytoplasma forms a distinct group from the Bermuda grass whiteleaf and sugarcane phytoplasmas, suggesting that Napier grass stunt should be in its own 'Candidatus Phytoplasma sp.'. The phytoplasmas associated with coconut and arecanut in southern India and Sri Lanka, which are in the same 16SrXI group, appear in different groups based on secA analysis.
\end{abstract}

Phytoplasmas are a diverse group of small, cell-wall-less bacteria within the class Mollicutes that are transmitted between plants by hemipteran insect vectors and infect numerous important food, fiber, fodder, and timber crops, causing significant crop losses (Hogenhout et al. 2008). Because phytoplasmas cannot be feasibly cultured in vitro, they are classified based on sequencing of the $16 \mathrm{~S}$ ribosomal RNA (rRNA) gene and, during the 1990s, a scheme for classification based upon restriction fragment length polymorphism (RFLP) profiles of the 16S rRNA gene was developed (Lee et al. 1993). Subsequently, a parallel system, also based on the 16S rRNA, has been developed that groups phytoplasmas into the novel candidate taxon 'Candidatus Phytoplasma' (IRPCM Phytoplasma/Spiroplasma Working Team-Phytoplasma taxonomy group 2004).

Although taxonomy based on the highly conserved 16S rRNA gene has been useful for primary classification purposes, most DNA-based bacterial classifications now make use of multilocus sequence typing (MLST) to provide more detailed classifications where, typically, as many as 10 genes are examined. In numerous cases, this approach has allowed taxonomic restructuring (Martens et al. 2008; Schoch et al. 2006), with each gene providing different levels of evolutionary information (Gürtler and Mayall 2001). Few attempts have been made to study genes other than the 16S rRNA gene across the phytoplasmas, primarily due to the difficulty in designing universal primers that can be used to amplify the genes across all $16 \mathrm{Sr}$ groups. Nevertheless several alternative genes have been evaluated for finer differentiation of phytoplasmas, mostly within a given $16 \mathrm{Sr}$ group, and this has been

Corresponding author: M. Dickinson;

E-mail: matthew.dickinson@nottingham.ac.uk

*The $\boldsymbol{e}$-Xtra logo stands for "electronic extra" and indicates that four supplementary figures are published online.

Accepted for publication 4 June 2016.

http://dx.doi.org/10.1094/PDIS-02-16-0244-RE

(C) 2016 The American Phytopathological Society highly informative (Arnaud et al. 2007; Hodgetts et al. 2008; Makarova et al. 2012). Recent advances in DNA sequence technology to include high-throughput sequencing has permitted sequencing of a limited number of complete phytoplasma genomes (Bai et al. 2006; Chung et al. 2013; Kube et al. 2008; Oshima et al. 2004; Tran-Nguyen et al. 2008), such that it is now possible to attempt to design additional sets of universal primers that can be used in MLST analysis across the range of phytoplasmas to facilitate taxonomic restructuring.

Phytoplasmas of gramineous plants, including sugarcane (Saccharum officinarum), rice (Oryzae sativa), Napier grass (Pennisetum purpureum), and Bermuda grass (Cynodon dactylon), are mainly classified into two $16 \mathrm{Sr}$ groups and 'Candidatus Phytoplasma spp.' based on $16 \mathrm{~S}$ rRNA analysis, with those of sugarcane, rice, and Napier grass in 16SrXI 'Candidatus Phytoplasma oryzae' (Asudi et al. 2016a,b; Jones et al. 2004; Jung et al. 2003) and those of Bermuda grass in 16SrXIV ' $C a$. P. cynodontis' (Lee et al. 1998). Several sugarcane phytoplasma diseases have been described, including sugarcane whiteleaf (SCWL), sugarcane grassy shoot (SCGS), sugarcane yellow leaf (SCYL), and Ramu stunt disease (Marcone 2002). In many parts of Asia and Australia, SCWL and SCGS are a major threat to sugarcane cultivation (Blanche et al. 2003), while SCYL and yellows diseases have been found in Asia, Cuba, and South Africa (Arocha et al. 2005). Based on the 16S rRNA, the SCWL and SCGS phytoplasmas are closely related to rice yellow dwarf (RYD) disease and Napier grass stunt (NGS), with Bermuda grass whiteleaf (BGWL) disease being more distantly related and, therefore, in a separate $16 \mathrm{Sr}$ group. This is different from the SCYL disease in Cuba, which has been classified into a new 16SrXVI group (Wei et al. 2007); the sugarcane yellows of South Africa, which is in 16SrIII; and SCYL disease in India, which has been placed in 16SrI-B (Kumar et al. 2015).

The most characteristic symptoms of SCWL are the bearing of leaves with total chlorosis in a whorl of green leaves, proliferation of tillers, and stunting, whereas SCGS is characterized by the production of a large number of thin, slender, adventitious tillers bearing white or pale yellow leaves and profuse growth giving a bushy or grassy appearance. However, there has been confusion in the literature as to whether these two types of symptoms are caused by the same or different phytoplasmas. In Thailand, Wongkaew et al. (1997) 
reported that SCWL and SCGS are caused by two different phytoplasmas based on a DNA sequence containing the $3^{\prime}$ end of the 16S rRNA and the spacer region between the 16S rRNA and transfer RNA (tRNA), and RFLP digest patterns. However, Nasare and Yadav (2007) concluded from analysis of the 16S-23S rRNA spacer region of SCWL and SCGS phytoplasmas in India that they belong to the same group and, more recently, Viswanathan et al. (2011) also concluded that sequence similarity between SCWL and Indian SCGS phytoplasmas is $>99.6 \%$ and restriction of the amplicons with a set of restriction enzymes did not show any polymorphism among them. Interestingly, recent work also using sequencing of the $16 \mathrm{~S}-23 \mathrm{~S}$ spacer region has concluded that the yellow leaf symptoms of sugarcane are an early symptomatic stage of the SCWL phytoplasma in Thailand (Soufi et al. 2013).

Phytoplasmas associated with wilt diseases of coconut (Cocos nucifera) and arecanut palm (Arecha catechu) in Sri Lanka and southern India have also been classified into the 16SrXI sugarcane group based on 16S rRNA sequences (Kanatiwela-de Silva et al. 2015; Perera et al. 2012; Manimekalai et al. 2010; Ramaswamy et al. 2013). These wilt diseases, in which yellowing of young leaves is the main symptom, are quite different from the lethal yellowing-type diseases of coconut found in the Caribbean, Florida, Mexico, Tanzania, Nigeria, Ghana, and Mozambique, which have been classified into three 'Candidatus Phytoplasma spp.': 16SrIV 'Ca. P. palmae' and 16SrXXII 'Ca. P. palmicola' and ' $\mathrm{Ca}$. P. cocostanzaniae' (Harrison et al. 2014).

The aims of this study were to use MLST analysis, based on three genes-16S rRNA, secA, and leucyl tRNA synthetase (leuS), for which universal primers have recently been developed-to clarify the taxonomic relationships between the phytoplasmas of Napier grass, Bermuda grass, sugarcane, areca palm, and coconut palm in East Africa and South and Southeast Asia. This has important implications for determining the host ranges of these different phytoplasmas.

\section{Materials and Methods}

Plant material. Sugarcane leaf samples exhibiting typical symptoms of SCGS and SCWL disease were collected in two separate sampling periods in Sri Lanka. During 2010 to 2012, samples were collected from fields of the Sugarcane Research Institute at Udawalawe, Sri Lanka (6²6'18.04" N, 8053'18.44" E); fields at Sewanagala and Palawatta located in Uva Province; and fields at Hingurana located in the southeastern part of the Eastern Province, Sri Lanka. The locations are about $50 \mathrm{~km}$ away from each other. From each location, leaf samples from 10 plants showing each symptom were separately collected. Corresponding symptomless samples were also collected in the same fields and from tissue-cultured healthy plants maintained in net houses at the Sugarcane Research Institute at Udawalawe. These samples were sent to the University of Ruhuna for processing, with a subset sent to the United Kingdom. In the second collecting period in 2012 to 2013, a further 30 samples exhibiting SCGS symptoms and 30 exhibiting SCWL symptoms were collected at the Sugarcane Research Institute at Udawalawe and sent to the University of Colombo for processing. In addition, in 2013, two SCWL-infected plants were collected in Si Bun Rueang district $\left(17^{\circ} 03^{\prime} 07.5^{\prime \prime} \mathrm{N}, 102^{\circ} 14^{\prime} 24.6^{\prime \prime} \mathrm{E}\right)$, Nong Bua Lam Phu Province, Thailand and transported to the greenhouses at the University of Nottingham, where they were maintained for further processing. The SCGS from Vietnam used in this study was collected from Nghean Province in north-central Vietnam, as described by Hoat et al. (2012).

For coconut, there were also two separate collecting periods. Spear leaf samples were collected in 2010 from 10 'Sri Lankan tall' coconut palm trees showing symptoms of the disease referred to as Weligama coconut leaf wilt disease (WCLWD) located in Matara district ( $\left.5^{\circ} 28^{\prime} 26^{\prime \prime} \mathrm{N}, 80^{\circ} 25^{\prime} 46^{\prime \prime} \mathrm{E}\right)$, the Southern Province in Sri Lanka, with samples sent to the University of Ruhuna. Nonsymptomatic palm trees of the same cultivar were selected from the disease-free areas in the same province as negative controls. Further sampling was then continued between November 2010 and April 2014 in the same area by staff at the Matara regional center of the Coconut Research Institute, with 207 samples from symptomatic and 192 from symptomless palm trees being sent to the University of Colombo for processing.
A small number of samples were also sent to the United Kingdom for separate analysis.

For areca palm, 15 samples were collected from palm trees showing areca yellow leaf disease (AYLD) symptoms in the WCLWD plantations and processed at the University of Colombo, while, for BGWL, 3 samples from the Weligama area in southern Sri Lanka $\left(5^{\circ} 28^{\prime} 26^{\prime \prime} \mathrm{N}\right.$, $\left.80^{\circ} 25^{\prime} 46^{\prime \prime} \mathrm{E}\right)$ and 25 samples from the Kalutara district $\left(6^{\circ} 42^{\prime} 48^{\prime \prime} \mathrm{N}\right.$, $79^{\circ} 54^{\prime} 15^{\prime \prime}$ E) in southwest Sri Lanka were collected and processed at the University of Ruhuna and University of Colombo, and a further 1 sample of Bermuda grass and five samples of Digitaria spp. grasses showing yellowing symptoms were collected from the Ethiopia rift valley area by Berhanu Bekele (Ethiopian Institute of Agricultural Research, Ambo, Ethiopia) in 2009 (collecting area as described by Bekele et al. 2011) and sent to the University of Nottingham for processing. Napier grass plants positive for NGS phytoplasma originating from Kenya have been maintained in the greenhouses in the Department of Plant Sciences, University of Nottingham, for the past 12 years and were also included in these studies. The origins of samples used for the phylogenetic analysis in this study are summarized in Table 1.

DNA extraction. DNA was extracted from $0.5 \mathrm{~g}$ of leaves dried on silica gel or fresh samples preserved at $-80^{\circ} \mathrm{C}$. The tissue was ground in liquid nitrogen and DNA was extracted by the cetyltrimethylammonium bromide method of Doyle and Doyle (1990). DNA samples that failed to support polymerase chain reaction (PCR) were cleaned up, if necessary, using polyvinylpolypyrrolidone in a spin column according to Cullen and Hirsch (1998). Concentrations and purity of DNA were estimated spectrophotometrically.

Analysis of 16S rRNA and $\operatorname{secA}$ regions. DNA extracted from symptomatic and symptomless samples was used as template for amplification by direct and nested PCR. The phytoplasma universal primer pair P1 (Deng and Hiruki 1991) and P7 (Schneider et al. 1995) was used in the first round of PCR, with amplifications performed in a thermocycler using $1 \mathrm{~min}\left(2 \mathrm{~min}\right.$ for an initial denaturation) at $94^{\circ} \mathrm{C}, 1 \mathrm{~min}$ at $55^{\circ} \mathrm{C}$, and $1 \mathrm{~min} 30 \mathrm{~s}$ at $72^{\circ} \mathrm{C}$ for 35 cycles; and a final extension at $72^{\circ} \mathrm{C}$ for $10 \mathrm{~min}$. The $\mathrm{P} 1 / \mathrm{P} 7$ reaction product $(1 \mu \mathrm{l}$ for coconut and areca palm samples) or $1 \mu l$ of $1 / 40$ dilutions in water (for samples from other plants) was used as the template in nested PCR using primer pair R16F2n (Gundersen and Lee 1996) and R16R2 (Lee et al. 1993) or fU5/rU3 (Lorenz et al. 1995). In the nested PCR assays, conditions were the same as in the first round of PCR, apart from the annealing temperature at $60^{\circ} \mathrm{C}$ and 30 cycles.

For the $\sec A$ gene, the primers secAfor1 and secArev1 (Table 2) were used and the PCR conditions were $94^{\circ} \mathrm{C}$ for $2 \mathrm{~min}$; followed by 35 cycles of $94^{\circ} \mathrm{C}$ for $30 \mathrm{~s}, 43^{\circ} \mathrm{C}$ for $30 \mathrm{~s}$, and $72^{\circ} \mathrm{C}$ for $90 \mathrm{~s}$; and a final extension step of $72^{\circ} \mathrm{C}$ for $10 \mathrm{~min}$. Resultant PCR products were diluted as for $16 \mathrm{~S}$ rRNA PCR and used in nested PCR with primers secAfor 2 and secArev2 using the same conditions as above, except for an annealing temperature of $53^{\circ} \mathrm{C}$.

Primer design for the leuS gene. To develop an alternative set of universal primers that could be used for improved phylogenetic analyses, genes from the recently sequenced $16 \mathrm{SrXI}$ NGS genome (P. Kawicha, unpublished) that were also present in the already sequenced 16SrI, 16SrX, and 16SrXII genomes (Bai et al. 2006; Kube et al. 2008; Oshima et al. 2004; Tran-Nguyen et al. 2008) were selected, because the 16SrXI group is in a cluster phylogenetically distinct from the other phytoplasmas and, therefore, likely to show the most significant sequence variation. Therefore, if sequences could be found from which it was possible to design primers that were common between these very diverse phylogenetic groups, it is possible that such primers would also work on all the other as yet unsequenced phylogenetic groups. Such potential primers were then analyzed against the Acholeplasma laidlawii genome sequence to rule out any that might not be specific to just the phytoplasmas. Based on this approach, the primers for the leuS gene were developed (leufor 1 plus leurev 1 in the first round and leufor 2 plus leurev 2 in the second round; Table 2) and initially validated on 14 diverse phytoplasma samples belonging to seven different phylogenetic groups, along with a healthy periwinkle plant sample as control. These primers were found to work as nested PCR primers using the same conditions as for the secA gene, and amplified a sequence of approximately $1,120 \mathrm{bp}$. They were subsequently used 
on a range of phytoplasma DNA and plant samples held in the phytoplasma collection at the University of Nottingham to produce the sequences used in the phylogenetic analysis in this study (Table 1).

All PCR was performed with Ready-to-Go PCR beads (GE Healthcare, Buckinghamshire, UK) in $25-\mu 1$ reactions containing $0.5 \mu \mathrm{l}$ of each of the appropriate forward and reverse primers $(10 \mathrm{nM} / \mu \mathrm{l})$, $1 \mu \mathrm{l}$ of template DNA, and $23 \mu \mathrm{l}$ of sterile distilled water. Aliquots of $5 \mu \mathrm{l}$ of each final reaction mixture were resolved by $1 \%$ agarose gels using Tris-borate EDTA ( $90 \mathrm{mM}$ Tris-borate and $2 \mathrm{mM}$ EDTA) as the running buffer. Gels were stained in ethidium bromide, visualized by
UV transillumination, and photographed. The presence of PCRamplifiable DNA was confirmed for samples that were negative with phytoplasma primers using primers based on the cox gene (Tomlinson et al. 2010).

Cloning and sequencing of PCR products. The nested PCR products were purified by PCR product clean up kit (Sigma, Poole, UK) according to the manufacturer's protocol. Cleaned PCR products were ligated into the pGEM-T easy vector system (Promega, Southampton, UK) and cloned into Escherichia coli JM109 cells following the manufacturer's instructions. Clone inserts were amplified

Table 1. Phytoplasma strains sequenced in this study ${ }^{a}$

\begin{tabular}{|c|c|c|c|c|c|}
\hline Code & Isolate name & Notes on origin of sample & 16Sr group & $\sec A$ sequence & leuS sequence \\
\hline BCRD & Blackcurrant reversion disease & $\begin{array}{l}\text { Catharanthus roseus plant in UoN } \\
\text { collection; original isolation from } \\
\text { the Czech Republic }\end{array}$ & 16SrI-C & EU168723 & KU751791 \\
\hline SOYP & Soybean phyllody & $\begin{array}{l}\text { C. roseus plant in UoN collection; } \\
\text { original isolation from Thailand }\end{array}$ & 16 SrII-C & EU168727 & KU751792 \\
\hline FBP & Faba bean phyllody & $\begin{array}{l}\text { C. roseus plant in UoN collection; } \\
\text { original isolation from Sudan }\end{array}$ & 16SrII-C & EU168725 & KU751793 \\
\hline PYLV & Peach western $\mathrm{X}$ & $\begin{array}{l}\text { C. roseus plant in UoN collection; } \\
\text { original isolation from the United States }\end{array}$ & $16 \mathrm{SrIII}$ & EU168732 & KU751794 \\
\hline LNI & Plum leptonecrosis & $\begin{array}{l}\text { C. roseus plant in UoN collection; } \\
\text { original isolation from Italy }\end{array}$ & 16SrIII-B & nd & KU751795 \\
\hline LYAM & $\begin{array}{l}\text { Coconut lethal yellowing } \\
\text { (Adonidia merrillii) }\end{array}$ & $\begin{array}{l}\text { DNA sample from N. Harrison, Florida; } \\
\text { original isolation from Florida }\end{array}$ & 16SrIV-A & EU168736 & KU751796 \\
\hline EY & Elm yellows & $\begin{array}{l}\text { DNA sample from A. Bertaccini, Bologna, } \\
\text { Italy; original isolation from the } \\
\text { United States }\end{array}$ & $16 \mathrm{SrV}-\mathrm{A}$ & EU168741 & KU751797 \\
\hline PWB & Potato witches'-broom & $\begin{array}{l}\text { C. roseus plant in UoN collection; } \\
\text { original isolation from the United States }\end{array}$ & 16SrVI-A & EU168742 & KU751798 \\
\hline BLL & Brinjal little leaf & $\begin{array}{l}\text { C. roseus plant in UoN collection; } \\
\text { original isolation from India }\end{array}$ & 16SrVI-A & EU168743 & KU751799 \\
\hline AP-15 & Apple proliferation & $\begin{array}{l}\text { DNA sample from A. Bertaccini, Bologna, } \\
\text { Italy; original isolation from Italy }\end{array}$ & $16 \mathrm{SrX}-\mathrm{A}$ & EU168747 & KU751800 \\
\hline NGS & Napier grass stunt & $\begin{array}{l}\text { Pennisetum purpureum plant in UoN } \\
\text { collection; original isolation from Kenya }\end{array}$ & $16 \mathrm{SrXI}$ & EU168750 & KU751801 \\
\hline BVK & Flower stunting & $\begin{array}{l}\text { DNA sample from A. Bertaccini, Bologna, } \\
\text { Italy; original isolation from Germany }\end{array}$ & $16 \mathrm{SrXI}$ & nd & KU751802 \\
\hline SCWL1 & $\begin{array}{l}\text { Sugarcane whiteleaf } \\
\text { first sampling }\end{array}$ & $\begin{array}{l}\text { Plant material sampled from Uva Province, } \\
\text { Sri Lanka in } 2011\end{array}$ & 16SrXI JF754438 & JF754450 & KU751803 \\
\hline SCWL2 & $\begin{array}{l}\text { Sugarcane whiteleaf } \\
\text { second sampling }\end{array}$ & $\begin{array}{l}\text { Plant material sampled from Udawalawe, } \\
\text { Sri Lanka in } 2013\end{array}$ & $16 \mathrm{SrXI}$ & KU751785 & KU751804 \\
\hline SCWL3 & Sugarcane whiteleaf Thailand & $\begin{array}{l}\text { Plant material sampled from Nong Bua } \\
\text { Lam Phu Province, Thailand in } 2013\end{array}$ & $16 \mathrm{SrXI}$ & nd & KU751805 \\
\hline SCGS1 & $\begin{array}{l}\text { Sugarcane grassy shoot } \\
\text { first sampling }\end{array}$ & $\begin{array}{l}\text { Plant material sampled from Eastern } \\
\text { Province, Sri Lanka in } 2011\end{array}$ & 16SrXI JF754440 & JF754452 & KU751806 \\
\hline SCGS2 & $\begin{array}{l}\text { Sugarcane grassy shoot } \\
\text { second sampling }\end{array}$ & $\begin{array}{l}\text { Plant material sampled from Udawalawe, } \\
\text { Sri Lanka in } 2013\end{array}$ & $16 \mathrm{SrXI}$ & KU751786 & KU751807 \\
\hline SCGS3 & $\begin{array}{l}\text { Sugarcane grassy } \\
\text { shoot Vietnam }\end{array}$ & $\begin{array}{l}\text { Plant material sampled from Nghean } \\
\text { Province, Vietnam in } 2010\end{array}$ & 16SrXI JF754442 & JF754457 & nd \\
\hline WCLWD1 & $\begin{array}{l}\text { Weligama coconut leaf wilt } \\
\text { disease first sampling }\end{array}$ & $\begin{array}{l}\text { Plant material sampled from Southern } \\
\text { Province, Sri Lanka in } 2010\end{array}$ & $16 \mathrm{SrXI}$ & KU751787 & nd \\
\hline WCLWD2 & $\begin{array}{l}\text { Weligama coconut leaf wilt } \\
\text { disease second sampling }\end{array}$ & $\begin{array}{l}\text { Plant material sampled from Southern } \\
\text { Province, Sri Lanka in } 2013\end{array}$ & $16 \mathrm{SrXI}$ & KU751788 & nd \\
\hline APYL & $\begin{array}{l}\text { Areca palm yellow } \\
\text { leaf disease }\end{array}$ & $\begin{array}{l}\text { Plant material sampled from Southern } \\
\text { Province, Sri Lanka in } 2013\end{array}$ & $16 \mathrm{SrXI}$ & KU751789 & nd \\
\hline BGWL1 & Bermuda grass whiteleaf & $\begin{array}{l}\text { Plant material sampled from Cynodon } \\
\text { dactylon, Ethiopia in } 2009\end{array}$ & 16SrXIV & KU751790 & KU751808 \\
\hline BGWL2 & Bermuda grass whiteleaf & $\begin{array}{l}\text { Plant material sampled from Digitaria sp., } \\
\text { Ethiopia in } 2009\end{array}$ & 16SrXIV & nd & KU751809 \\
\hline BGWL3 & Bermuda grass whiteleaf & $\begin{array}{l}\text { Plant material sampled from } \\
\text { Cynodon dactylon, Sri Lanka in } 2011\end{array}$ & 16SrXIV JF754443 & JF754454 & KU751810 \\
\hline STOL & Stolbur of pepper & $\begin{array}{l}\text { DNA sample from A. Bertaccini, } \\
\text { Bologna, Italy; original isolation } \\
\text { from Serbia }\end{array}$ & $16 \mathrm{SrXII}-\mathrm{A}$ & EU168752 & KU751811 \\
\hline CSPWD & Ghanaian Cape St Paul wilt & $\begin{array}{l}\text { Coconut trunk boring sample from Ghana, } \\
\text { collected in } 2011\end{array}$ & 16SrXXII KF419286 & EU168740 & KU751812 \\
\hline LYDM & $\begin{array}{r}\text { Coconut lethal yellows } \\
\text { disease Mozambique }\end{array}$ & $\begin{array}{l}\text { Coconut trunk boring sample from } \\
\text { Mozambique, collected in } 2007\end{array}$ & 16SrXXII E549768 & nd & KU751813 \\
\hline
\end{tabular}

\footnotetext{
${ }^{a}$ GenBank accessions obtained as part of this study are shown; nd = not done.

${ }^{\mathrm{b}} \mathrm{UoN}=$ University of Nottingham.
} 
from transformant colonies by PCR using primers M13for and M13rev, and sequencing was performed by Eurofins (Ebersberg, Germany). Sequences have been deposited at GenBank under accession numbers listed in Table 1.

Phylogenetic analysis. BLAST searches were performed at the National Center for Biotechnology Information (NCBI) website (http://www.ncbi.nlm.nih.gov/), and alignment of the nucleotide and amino acid sequences was performed in MEGA v. 60.06 (Tamura

Table 2. Sequences of the $\sec A$ and $l e u S$ gene primers developed and used in this study

\begin{tabular}{|c|c|c|}
\hline Primer name & Sequence $\left(5^{\prime}-3^{\prime}\right)$ & $\begin{array}{c}\text { Previous } \\
\text { publication }\end{array}$ \\
\hline SecAfor1 & GARATGAAAACTGGRGAAGG & Hodgetts et al. 2008 \\
\hline SecAfor2-u & ASTCGTGAAGCTGAAGG & Bekele et al. 2011 \\
\hline SecAfor2-1 & AGCTAAAAGAGAATTTGAAGG & Bekele et al. 2011 \\
\hline SecAfor2-Ly & CTGATAGAGAAGCTAATGG & Bekele et al. 2011 \\
\hline $\begin{array}{l}\text { SecAfor2- } \\
\text { BGW }\end{array}$ & CTCAAAGAGAAGCGAAAGG & This study \\
\hline SecArev1 & GCAGTTCCTGTCATYCCTGA & This study \\
\hline SecArev2 & CCNTCRCTAAATTGNCGTCC & Bekele et al. 2011 \\
\hline SecArev2a & CCNTCRCTAAATTGNCTACC & This study \\
\hline Leufor1 & GATATGTTTCCTTATCCTTC & This study \\
\hline Leufor2 & CATCCTTTTGGTTGGGATTC & This study \\
\hline Leurev1 & TACCAAGARCTTCCWGC & This study \\
\hline Leurev2 & CTSCCCAATATCTTTGRCG & This study \\
\hline
\end{tabular}

et al. 2013) using the packages CLUSTAL W and MUSCLE, respectively (Thompson et al. 1994). The analysis was followed by a phylogenetic reconstruction by neighbor-joining using the bootstrap method (with 1,000 replications) as a test of phylogeny and maximum composite likelihood as the model.

\section{Results}

Disease symptoms. The survey of different sugarcane cultivation fields in Sri Lanka revealed that two major symptom types were prevalent - total chlorosis, slender leaves in a whorl of green leaves without grassy appearance (SCWL; Fig. 1A), and profusely proliferated grassy shoots with white or pale yellow leaves (SCGS; Fig. 1B). These two types of disease were equally distributed in all the examined locations regardless of cultivars.

For the coconut (WCLWD), unusual yellowing of younger fronds of palm trees was observed mainly in the southern part of Sri Lanka. The intense yellowing of lower whorls of fronds and occasional yellowing of mid whorls of fronds was also observed (Fig. 1C), along with flattening and downward bending of leaflets giving a flaccid appearance (Fig. 1D). For the areca palm (AYLD), foliar yellowing beginning from the inner whorl was the most conspicuous symptom.

Analysis of 16S rRNA gene sequences. In total, 60 sugarcane samples including nonsymptomatic plants collected from different sites in Sri Lanka were analyzed in the first sampling period. All the sugarcane samples exhibiting symptoms characteristics for SCGS and SCWL (10 samples of each) were positive by PCR amplification producing phytoplasma-specific DNA products of $1.2 \mathrm{~kb}$ and $890 \mathrm{bp}$ when nested with R16F2n/R16R2 and fU5/rU3, respectively (results
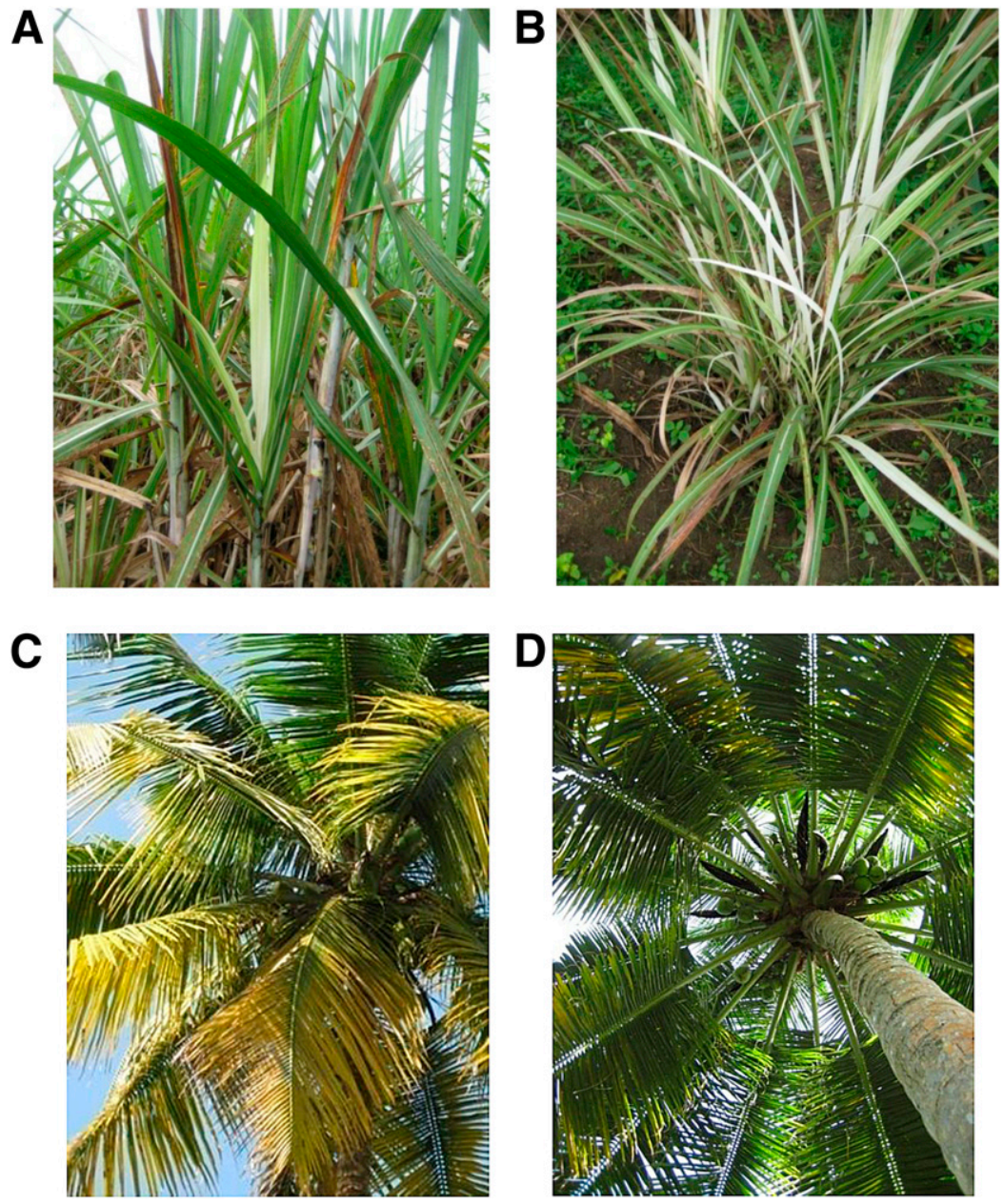

Fig. 1. Symptomatic sugarcane plants showing phytoplasma infection: A, sugarcane plant showing sugarcane whiteleaf symptoms, white leaves in a whorl of green leaves and B, sugarcane plant showing sugarcane grassy stunt symptoms, proliferation of shoots, white and yellow narrow leaves, grassy appearance. Symptomatic coconut plants showing Weligama coconut leaf wilt disease symptoms: C, unusual yellowing of younger leaves and $\mathbf{D}$, leaf flaccidity or flattering condition. 
not shown). From the second sampling period, a further 10 SCGS and 10 SCWL samples were screened with the rRNA primers and all gave PCR products. No amplification was observed with any set of phytoplasma primers from DNA when the nonsymptomatic samples were used as template.

For the coconut, only 4 of 10 samples showing WCLWD symptoms from the first screening gave PCR products, and no amplification was observed from the healthy samples (results not shown). In the second screening, all 20 symptomatic samples tested gave PCR products but $60 \%$ of the symptomless palm trees from the same area (20 samples) also gave PCR products with these primers. For the areca palm (10 samples tested) and BGWL (10 samples tested), all the symptomatic samples gave PCR products with the rRNA primers; however, as noted below, sequencing showed that not all of the PCR products obtained were phytoplasma DNA and, therefore, positive PCR results with the 16S rRNA primers alone should be treated with caution. It was also noted that the WCLWD phytoplasma DNA appeared to be unstable, in that DNA had to be extracted and amplified within 1 week of sampling to obtain positive results; when these DNA extracts were subsequently stored at $-20^{\circ} \mathrm{C}$, they lost the capacity for phytoplasma DNA amplification.

The sequences of representative phytoplasmas from diseased sugarcane in Sri Lanka and Vietnam were determined (at least five separate samples were sequenced from the Sri Lankan sampling for each disease symptom, location, and sampling period, and all sequences were found to be identical to the reference sequences shown in Table 1). Sequence alignments (Fig. 2) revealed that the sugarcane samples, which were collected from different areas and at different times, showed $>99 \%$ sequence identity in their $16 \mathrm{~S}$ rRNA to each other, despite producing significantly different symptoms. BLAST searches for the 16S rRNA sequences reported in this article-Sri Lankan SCWL (accession number JF754438), Sri Lankan SCGS (JF754440), and Vietnamese SCGS (JF754442) -indicated $>99 \%$ sequence identity with previously published sequences for SCWL from Thailand (e.g., FM208258), SCGS from India (e.g., AM261831), SCWL from India (AB052874), Kerala coconut root wilt phytoplasma from India (GQ850122 and JX273772), arecanut yellow leaf disease from India (JN967909), and WCLWD from Sri Lanka (EU635503). This confirmed that the phytoplasmas associated with sugarcane in Sri Lanka belong to a group most closely aligned to the RYD 16SrXI group of ' $\mathrm{Ca}$. P. oryzae' based on the $16 \mathrm{~S}$ rRNA.

Analysis of the coconut 16S rRNA sequences amplified with nested primers R16F2n/R16R2 in this study with the available sequences in the NCBI database indicated that all of the four initial samples showed 99\% sequence similarity with the sugarcane and coconut phytoplasmas detailed above (results not shown), confirming the association of a phytoplasma with WCLWD in Sri Lanka and the 16SrXI grouping reported by Perera et al. (2012). However, most of the 16S rRNA PCR products obtained from the second sampling, including apparently healthy palm trees, and from the areca palm in Sri Lanka, had the highest similarity (89\% identity) to an uncultured bacterium from grassland soil (JF754456).

The BGWL 16S rRNA sequencing from this study (JF754443) showed that these phytoplasmas group with previously sequenced Bermuda grass and Brachiaria grass samples from around the world (Fig. 2), forming a distinct group from the sugarcane and coconut phytoplasmas, the ' $C a$. P. cynodontis' group. The NGS phytoplasma, which has been designated as a 16SrXI phytoplasma, is distinct from both the sugarcane and Bermuda grass groups (Fig. 2).

Analysis of $\boldsymbol{s e c} \boldsymbol{A}$ gene sequences. A partial sequence (420 bp) of the secA gene was determined for selected phytoplasmas from SCGS and SCWL plants from Sri Lanka and Vietnam, Bermuda grass plants from Sri Lanka and Ethiopia, and WCLWD and AYLD from Sri Lanka. PCR products of the correct size were obtained following nested PCR from 29 of 30 SCWL samples, 30 of 30 SCGS samples, 25 of 25 BGWL samples, 12 of 15 AYLD palm trees, 197 of 207 WCLWD palm trees, and 0 of 192 symptomless coconut palm. All the PCR products sequenced (10 from each of the plant species mentioned above) gave consistent sequences, indicating that the primers were only amplifying phytoplasma DNA and not other bacteria. These sequences were compared with each other and with those already reported in the database from India and worldwide and the phylogenetic tree, constructed by the neighbor-joining method with 1,000 bootstrap replications, is presented in Figure 3. The multiple alignments revealed that these phytoplasmas from sugarcane were identical. All the SCWL and SCGS formed a strong phylogenetic subcluster judged by branch length and bootstrap values of $100 \%$. Furthermore, all the 16SrXIV BGWL phytoplasmas grouped together and were separate from SCGS and SCWL, with a bootstrap value of $99 \%$, while the 16SrXI NGS (EU168750) formed its own lineage separate from the sugarcane and BGWL phytoplasmas. The analysis of sequences that were generated by the secA nested primers provided an interesting result for the Sri Lankan WCLWD and AYLD samples, placing them in the BGWL cluster, even though the 16S rRNA sequences had put WCLWD in the sugarcane group. This is distinct from the results obtained for the Kerala wilt and arecanut phytoplasmas from India, which were found to group with sugarcane samples based on both $16 \mathrm{~S}$ rRNA and secA sequencing. Unfortunately, no DNA sample of the 16SrXI-A RYD ' $C a$. P. oryzae' type member was available for this study; therefore, no $\sec A$ sequence of this type strain could be used in this analysis.

Analysis of leuS gene sequences. Although the secA primers gave fewer false positives in PCR than the $16 \mathrm{~S}$ rRNA primers, they only amplify a relatively short region of DNA. Therefore, attempts were made to develop a further set of universal primers that would amplify a longer region of DNA and potentially give additional phylogenetic information. Based on sequence analysis, a set of nested primers were designed that worked on all the phylogenetic groups tested and amplified a region of around 1,120 bp from part of the leuS gene. Interestingly, this sequence doesn't show only point mutations between different phytoplasma isolates but also some variation in the lengths of the region amplified, as shown in the amino acid sequence alignments (Supplementary Figures S1 to S4). This is particularly the case for the phytoplasmas of the gramineous plants, where there is a 5-amino-acid (aa) insertion between amino acids 170 and 180 (compared with aster yellows) for the sugarcane and Bermuda grass phytoplasmas and for BVK, the phytoplasma originating from a leafhopper (Psammotettix cephalotes) from Germany that has no associated disease (Jung et al. 2003). Furthermore, BVK has an additional 3-aa insertion between amino acids 160 and 170, while NGS has a similar 3-aa insertion between 160 and 170 plus an 8-aa insertion between 170 and 180 . There is also an 8-aa insertion between positions 330 and 340 for the coconut lethal yellowing phytoplasma, ' $\mathrm{Ca}$. P. palmae'; this same insertion was found for all three isolates that were sequenced from Adonidia merrillii, Hyophorbe verschafetii, and Phoenix rubicola (samples originally obtained from Dr. N. Harrison, University of Florida; results not shown).

Phylogenetic analysis (Fig. 4), based on the leuS nucleotide sequences, shows clear resolution of the 16SrXI SCWL and SCGS phytoplasmas into a single group and the 16SrXIV BGWL phytoplasmas into a separate group. The NGS and BVK phytoplasmas form a separate group that is also clearly distinct from both the $16 \mathrm{SrXI}$ and 16SrXIV groups, suggesting these should be reclassified into a separate group and 'Candidatus Phytoplasma spp.'. Unfortunately, and despite repeated attempts, the phytoplasmas from Sri Lankan coconut and areca palm could not be amplified using the leuS primers, possibly due to the instability of this DNA during transit between Sri Lanka and the United Kingdom, as noted above.

\section{Discussion}

Phytoplasma diseases of sugarcane cause enormous crop losses all over the world, including in Australia (Blanche et al. 2003), Cuba (Arocha et al. 2005), Sri Lanka (Kumarasinghe and Jones 2001), and Vietnam (Hoat et al. 2012). Coconut phytoplasmas associated with WCLWD in Sri Lanka also cause severe crop losses, mainly in the southern part of Sri Lanka (Perera et al. 2012), as does Kerala wilt in India (Manimekalai et al. 2010), while, in East Africa, NGS is a significant disease of this fodder crop (Asudi et al. 2016a,b; Obura et al. 2009). The disease of sugarcane showing excess tillering with chlorotic leaves, giving a grassy appearance, is referred to as SCGS, while symptoms of white leaves in the whorl of green leaves, stunting, 


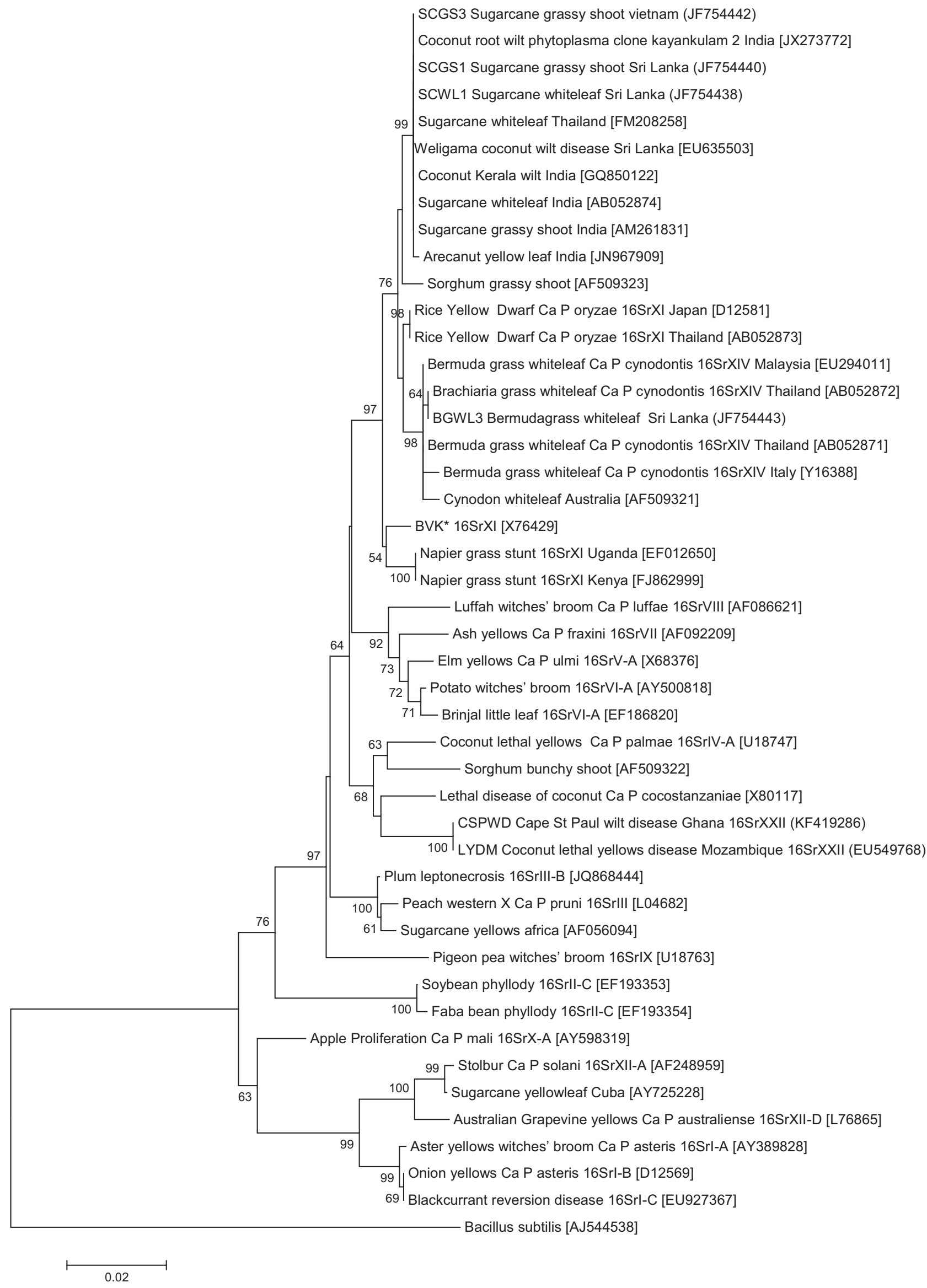

Fig. 2. Dendrograms constructed by the neighbor-joining method, showing the phylogenetic relationships among the sugarcane and grass phytoplasmas based on sequences of the 16S ribosomal RNA (rRNA) gene. GenBank accession numbers for previously published sequences are shown in brackets alongside the names of the phytoplasmas. Bootstrap values greater than $50 \%$ (expressed as percentages of 1,000 replications) are shown, and branch lengths are proportional to the number of inferred character state transformations. Bar $=$ substitutions per base 
and altered leaf texture is referred to as SCWL disease (Marcone 2002), and both types of symptoms are often seen in sugarcane cultivations in Sri Lanka, India, Thailand, and Vietnam. The presence of these two markedly different symptomatic plants in sugarcane in south and southeast Asia, including Sri Lanka, has led to the hypothesis that two different strains of sugarcane phytoplasmas are responsible (Ariyarathna et al. 2007; Wongkaew et al. 1997). However, in these studies, only the 16S rRNA or 16S-23S rRNA sequences were analyzed. More recent studies (Nasare and Yadav 2007; Viswanathan et al. 2011) have suggested that these two types of symptom are, in fact, caused by the same phytoplasma, a finding that has been confirmed in this current study, based on analysis of the additional secA and leuS sequences.
The findings of the sequence identity between the SCGS and SCWL phytoplasmas based on $\sec A$ and leuS led to a reexamination of the previous data that had suggested these phytoplasmas belonged to separate groups. In the analysis by Wongkaew et al. (1997), RFLP differences were described in the 16S rRNA sequence between SCGS and SCWL, although no $16 \mathrm{~S}$ rRNA sequences for these isolates were deposited in GenBank. Two sequences were presented in the article for the 16S-23S region (also not deposited at GenBank), which showed 5 nucleotide differences between the SCGS and SCWL sequences. However, if these two sequences are BLAST searched against sequences that have been deposited at NCBI for other sugarcane phytoplasmas, there are at least 10 nucleotide differences between both of them and any other sequences over a sequences length of 203

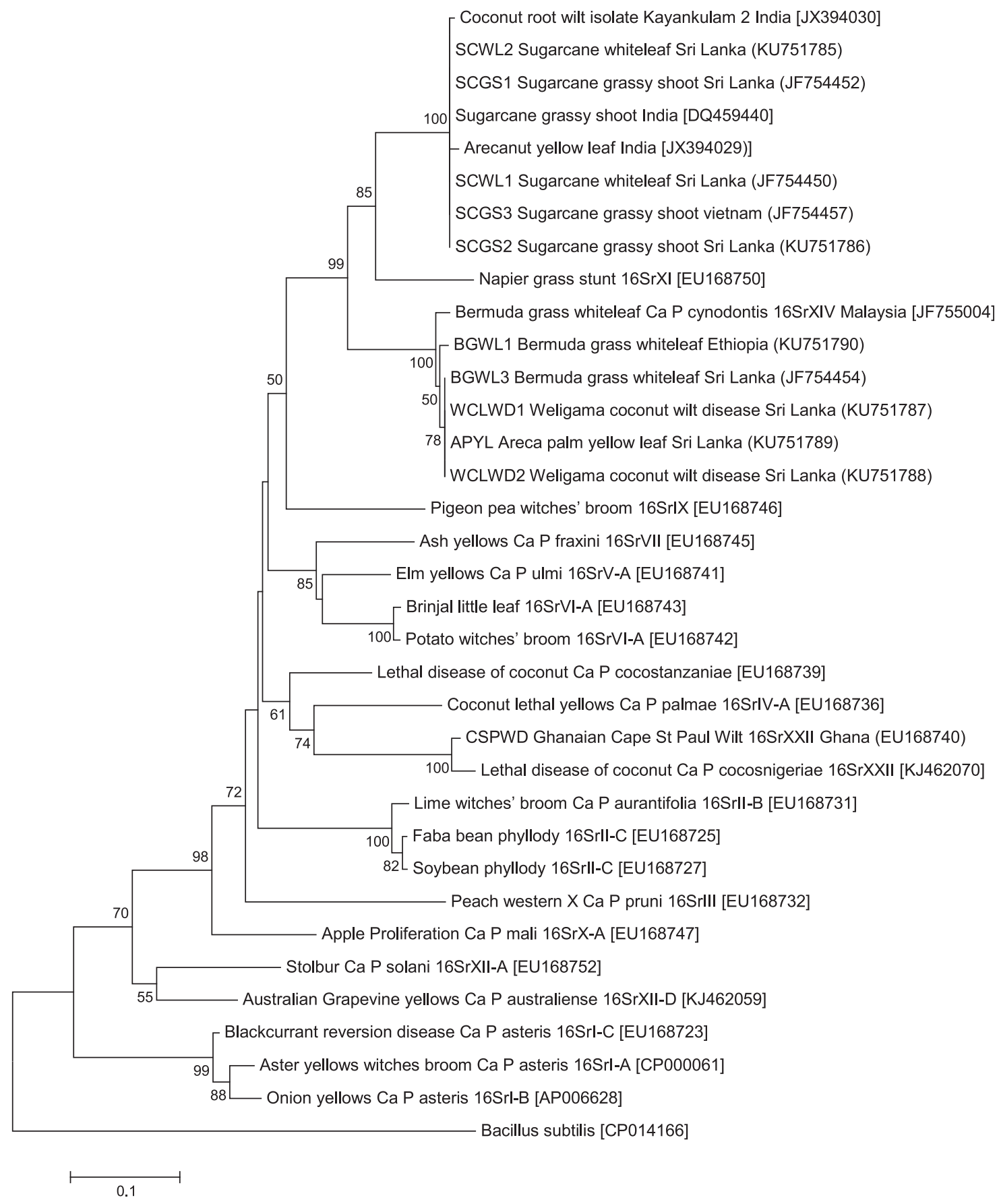

Fig. 3. Dendrograms constructed by the neighbor-joining method, showing the phylogenetic relationships among the sugarcane and grass phytoplasmas based on sequences of the $\sec A$ gene. GenBank accession numbers for previously published sequences are shown in brackets alongside the names of the phytoplasmas, while those obtained in this study are shown in parentheses. Bootstrap values greater than $50 \%$ (expressed as percentages of 1,000 replications) are shown, and branch lengths are proportional to the number of inferred character state transformations. Bar = substitutions per base. 
nucleotides, suggesting the sequences should be treated with caution. Similarly, a reexamination of many of the sequences deposited in GenBank that had previously suggested that Indian and Sri Lankan sugarcane phytoplasmas were different found that, if the sequences were more carefully examined and sequences trimmed to remove inaccurate $16 \mathrm{~S}$ and $23 \mathrm{~S}$ rRNA sequences, they were, in fact, identical throughout the $16 \mathrm{~S}$, tRNA, and partial $23 \mathrm{~S}$ regions. This highlights the importance of taking care when analyzing and basing conclusions on sequences deposited in databases and those cited in articles and not deposited in reference databases.

The 16S-23S rRNA intergenic spacer region was also used in the study of Nasare and Yadav (2007), where it was found that the phytoplasma isolates associated with grassy shoot and whiteleaf symptoms shared the same sequences, except for two samples, DQ380342 and DQ380343, which produced the same phenotypic symptoms but quite different sequences (79 and $84 \%$ identity, respectively, with other SCGS sequences). It has been recognized that phylogenetic analyses based on the $16 \mathrm{~S}-23 \mathrm{~S}$ region can be problematic, because this region is under few or no evolutionary constraints and, therefore, may be highly variable both within and between phytoplasma phylogenetic groups (Hodgetts et al. 2008). Because of this, MLST analysis in other bacterial systems generally uses coding sequences; hence the search for primers and sequences in the present study that could be used for this purpose in the phytoplasmas. Based on the results of this present study, the $\sec A$ and leuS genes show the necessary features for MLST analysis in that they have conserved regions for design of primers that work on a broad range of phytoplasma phylogenetic groups, combined with discriminatory sequences between these primers.

Because SCGS and SCWL appear to be caused by the same phytoplasma, there must be other reasons to account for the different symptoms. It has been suggested that some phytoplasma disease symptoms, including in sugarcane, only appear when specific environmental conditions prevail or when other disease organisms are also present (Tran-Nguyen et al. 2000) or related to the virulence status of strains. These could also be due to the factors such as soil type, micronutrient conditions, and so on but it appears unlikely to be due to host genotype for SCGS and SCWL, because the same cultivars of sugarcane were used in Sri Lanka during this current study. Interestingly, Soufi et al. (2013) have recently reported that another symptom found on sugarcane, yellow leaf, can also be attributed to the SCWL phytoplasma in Thailand although, in India, a 16SrI-B aster-yellows-type phytoplasma has been found associated with these same symptoms (Kumar et al. 2015). This is not unusual, because phytoplasmas from at least two different taxonomic groups have

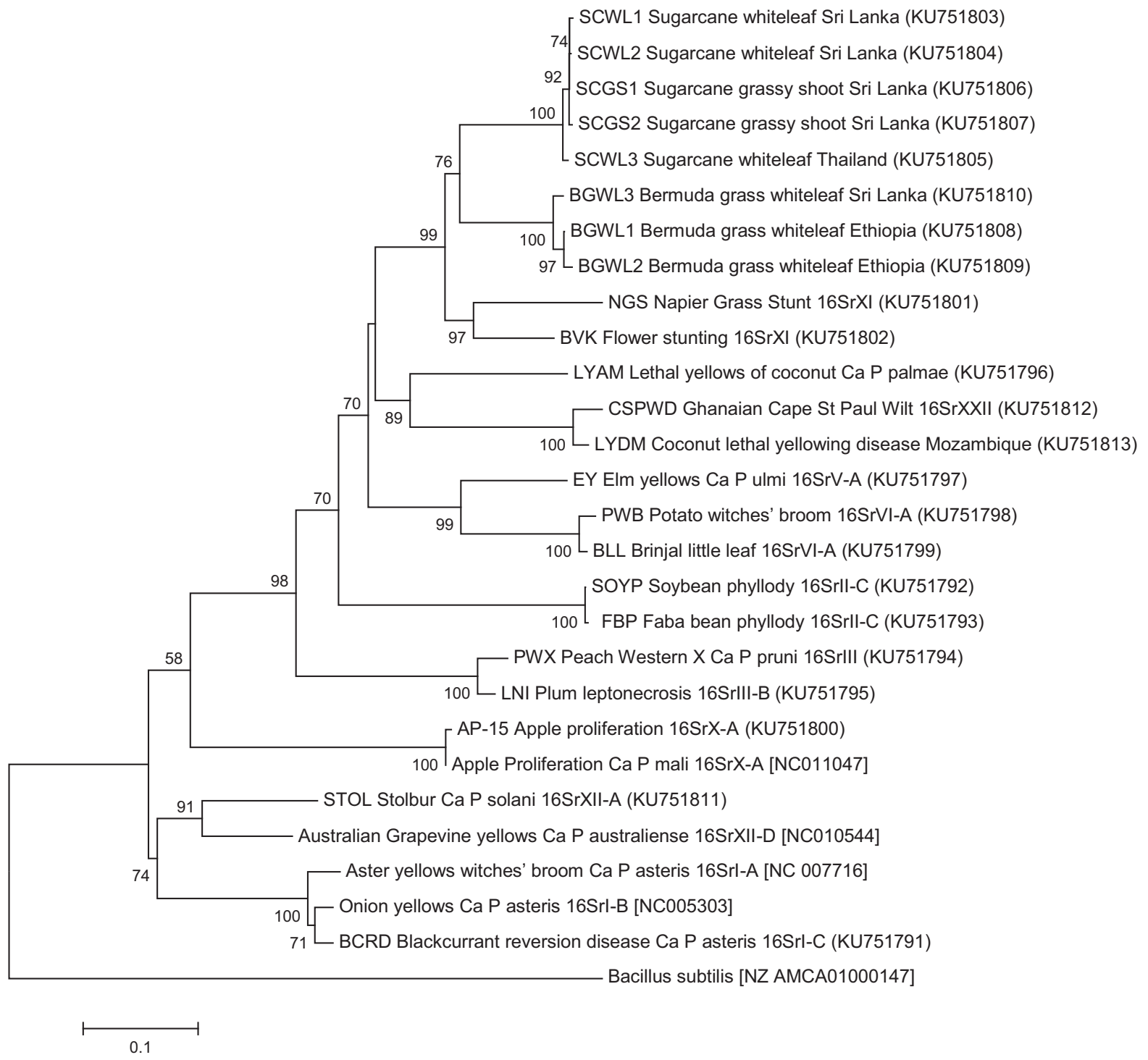

Fig. 4. Dendrograms constructed by the neighbor-joining method, showing the phylogenetic relationships among the sugarcane and grass phytoplasmas based on sequences of the leuS gene. GenBank accession numbers for previously published sequences are shown in brackets alongside the names of the phytoplasmas, while those obtained in this study are shown in parentheses. Bootstrap values greater than $50 \%$ (expressed as percentages of 1,000 replications) are shown, and branch lengths are proportional to the number of inferred character state transformations. Bar $=$ substitutions per base. 
been found associated with papaya dieback symptoms, along with an Erwinia sp. (Bekele et al. 2011). Further research is clearly needed to determine how the same phytoplasma can be associated with different symptoms in a plant host species, and also on how different phytoplasmas can be associated with the same symptoms.

The power of the secA and leuS genes was also shown in the analysis of the BGWL phytoplasmas from different parts of the world. Based on the 16S rRNA gene, these phytoplasmas form a tight grouping (Fig. 2). However, the secA sequence (Fig. 3) indicates differences between the Ethiopian and Sri Lanka samples, and this is more clearly shown by the leuS sequences (Fig. 4), where the samples from two different plant species from Ethiopia (Bermuda grass and Digitaria sp.) cluster in a separate subgroup, distinct from the BGWL from the Sri Lankan isolates. Examination of the amino acid sequence alignments indicates that there is, in fact, an additional amino acid at position 215 in the Ethiopian sequences compared with the Sri Lankan sequences. The leuS amino acid sequences also show length variation between other phytoplasmas, and it is interesting to note that the sequences from the gramineous plants (sugarcane, Bermuda grass, and Napier grass) and from coconut samples from the United States and the Caribbean tend to be longer than the sequences from other plant hosts and from coconut samples in Africa. The reasons for this are not known but they do indicate the potential power of these primers and this gene in phytoplasma phylogenetic analyses, and in confirming the host range of different phytoplasmas.

Based on this combined data, it is proposed that the classification of the NGS phytoplasma needs to be reconsidered. This phytoplasma was originally classified in the same $16 \mathrm{SrXI}$ group as RYD and the sugarcane phytoplasmas (Jones et al. 2004), yet this original article also suggested that the NGS 16S rRNA sequence was the most similar to BGWL (96\%). Clearly, there are still some anomalies in the 16SrXI/XIV grouping and subgrouping but the evidence from $16 \mathrm{~S}$ rRNA, secA, and leuS sequences presented in this article suggest that NGS is distinct from both the 16SrXI and XIV groups and should be in a new 'Candidatus Phytoplasma sp.'. Unfortunately, no secA or leuS sequences are available for the 16SrXI-A RYD type member of the ' $\mathrm{Ca}$. P. oryzae' group; these sequences would be valuable in the future for confirming this proposed reclassification, and the leuS gene could clearly be examined in other phytoplasmas for further taxonomic restructuring.

The anomalies in the 16SrXI/XIV grouping are also exemplified by the data for the coconut and areca palm samples from Sri Lanka (Kanatiwela-de Silva et al. 2015; Perera et al. 2012; this study) and from India (Manimekalai et al. 2010; Ramaswamy et al. 2013). The situation with these phytoplasmas is still not fully resolved, particularly because, despite repeated attempts, it was not possible to obtain any leuS sequences for the Sri Lankan samples in this study. Part of the problem with these phytoplasmas may be that they appear to be present in plants at very low titers (nested PCR assays generally need $1 \mu \mathrm{l}$ of first-round PCR product for successful amplification, as opposed to $1 / 40$ or greater dilutions for phytoplasmas from other plant hosts), and the DNA appears to be inherently unstable, in that attempts to freeze DNA extracts that are initially PCR positive for long periods have not been possible in the authors' experience. This, in turn, has resulted in difficulties in obtaining samples in the United Kingdom from Sri Lanka for studies with the leuS primers. Problems are compounded by the fact that the generally used 16S rRNA universal primers have been shown to often amplify DNA from coconut palm that sequencing subsequently shows is not of phytoplasma origin, as previously reported by Nejat et al. (2009). Therefore, it is not resolved as to whether these phytoplasmas associated with the wilt diseases of coconut and areca palm are the causal agents of the disease symptoms or secondary infections, perhaps being spread to the already symptomatic palm trees by vectors that have previously fed on other hosts such as sugarcane or Bermuda grass. This does not explain why the phytoplasmas identified in India and Sri Lanka appear to have the same 16S rRNA sequences indicative of sugarcane phytoplasmas but differ when it comes to $\sec A$ sequences, with the Indian phytoplasmas appearing to be in the sugarcane group and the Sri Lankan isolates appearing to be in the Bermuda grass group based on secA. However, multiple samples obtained from both areca palm and coconut at different collection times and from different locations in Sri Lanka, and analyzed in different laboratories (University of Nottingham, United Kingdom and University of Colombo, Sri Lanka), gave these same results, which clearly indicated that the $s e c A$ sequence of the Sri Lankan samples was of the BGWL type. It is possible that this is evidence of recombination having occurred between phytoplasma genomes but further studies are required to confirm whether this is the case and to determine the true nature of the association of phytoplasmas with these wilt diseases.

In summary, this study has shown the value of a new set of universal phytoplasma primers, based on the leuS gene, for phytoplasma classification and taxonomic restructuring. The sequences obtained show significant numbers of point mutations across the approximately 1,120-bp length of the amplified sequence, and consistent variations in length for phytoplasmas from particular phylogenetic groups, and even between phytoplasmas of the same group from different parts of the world, as shown for the BGWL samples. Such improved discrimination between samples will be invaluable in the future for monitoring the host range of particular phytoplasmas, the vector relationships, and the spread of phytoplasmas through different parts of the world.

\section{Acknowledgments}

S. Abeysinghe was a Commonwealth Academic Fellow from Sri Lanka and the work was supported by Commonwealth Scholarship Commission through the grant LKCF-2010-196. C. Kanatiwela-de Silva was partially funded by a British Society for Plant Pathology Junior Fellowship for her time in the United Kingdom. K. Warawichanee was funded by a Training and Research Fellowship Scholarship under the Agricultural Research Development Agency, Thailand. P. Kawicha was funded through the Royal Thai Government and Kasetsart University, Thailand. We thank TURIS grant Pro/DVC/0185 from University of Ruhuna, the Director and Research Officers at Sugarcane Research Institute of Sri Lanka for providing sugarcane samples; B. Bekele, Ethiopian Institute of Agricultural Research, for providing samples from Ethiopia; and T. X. Hoat, Plant Protection Research Institute, Dong Ngac, for providing samples from Vietnam. Phytoplasmas were held in the United Kingdom under DEFRA Plant Health License Number 103928/198432.

\section{Literature Cited}

Ariyarathna, H. A. C. K., Everard, J. M. D. T., and Karunanayake, E. H. 2007 Diseased sugarcane in Sri Lanka is infected with sugarcane grassy shoot and/ or sugarcane white leaf phytoplasma. Australas. Plant Dis. Notes 2:123-125.

Arnaud, G., Malembic-Maher, S., Salar, P., Bonnet, P., Maixner, M., Marcone, C., Boudon-Padieu, E., and Foissac, X. 2007. Multilocus sequence typing confirms the close genetic interrelatedness of three distinct flavescence dorée phytoplasma strain clusters and group $16 \mathrm{SrV}$ phytoplasmas infecting grapevine and alder in Europe. Appl. Environ. Microbiol. 73:4001-4010.

Arocha, Y., López, M., Piñol, B., Fernández, M., Picornell, B., Almeida, R., Palenzuela, I., Wilson, M. R., and Jones, P. 2005. 'Candidatus phytoplasma graminis' and 'Candidatus phytoplasma caricae', two novel phytoplasmas associated with diseases of sugarcane, weeds and papaya in Cuba. Int. J. Syst. Evol. Microbiol. 55:2451-2463.

Asudi, G. O., Van den Berg, J., Midega, C. A. O., Pickett, J. A., and Khan, Z. R. 2016a. The significance of Napier grass stunt phytoplasma and its transmission to cereals and sugarcane. J. Phytopathol. 164:378-385.

Asudi, G. O., Van den Berg, J., Midega, C. A. O., Schneider, B., Seemüller, E., Pickett, J. A., and Khan, Z. R. 2016b. Detection, identification and significance of phytoplasmas in wild grasses in East Africa. Plant Dis. 100:108-115.

Bai, X., Zhang, J., Ewing, A., Miller, S. A., Radek, A. J., Shevchenko, D. V., Tsukerman, K., Walunas, T., Lapidus, A., Campbell, J. W., and Hogenhout, S. A. 2006. Living with genome instability: The adaptation of phytoplasmas to diverse environments of their insect and plant hosts. J. Bacteriol. 188:3682-3696.

Bekele, B., Hodgetts, J., Tomlinson, J., Boonham, N., Nikolic, P., Swarbrick, P., and Dickinson, M. 2011. Use of a real-time LAMP isothermal assay for detecting $16 \mathrm{SrII}$ and $16 \mathrm{SrXII}$ phytoplasmas in fruit and weeds of the Ethiopian Rift Valley. Plant Pathol. 60:345-355.

Blanche, K. R., Tran-Nguyen, L. T. T., and Gibbs, K. S. 2003. Detection, identification and significance of phytoplasmas in grasses in northern Australia Plant Pathol. 52:505-512.

Chung, W.-C., Chen, L.-L., Lo, W.-S., Lin, C.-P., and Kuo, C.-H. 2013. Comparative analysis of the peanut witches'-broom phytoplasma genome reveals horizontal transfer of potential mobile units and effectors. PLoS One 8:e62770.

Cullen, D. W., and Hirsch, P. R. 1998. Simple and rapid method for direct extraction of microbial and from soil for PCR. Soil Biol. Biochem. 30:983-993.

Deng, S., and Hiruki, D. 1991. Amplification of 16S rRNA genes from culturable and nonculturable mollicutes. J. Microbiol. Methods 14:53-61. 
Doyle, J. J., and Doyle, J. L. 1990. Isolation of plant DNA from fresh tissue. Focus 12:13-15.

Gundersen, D. E., and Lee, I.-M. 1996. Ultrasensitive detection of phytoplasmas by nested-PCR assays using two universal primer pairs. Phytopathol. Mediterr. 35:144-151.

Gürtler, V., and Mayall, B. C. 2001. Genomic approaches to typing, taxonomy and evolution of bacterial isolates. Int. J. Syst. Evol. Microbiol. 51:3-16.

Harrison, N., Davis, R. E., Oropeza, C., Helmick, E., Narvaez, M., Eden-Green, S., Dollet, M., and Dickinson, M. 2014. 'Candidatus Phytoplasma palmicola', a novel taxon associated with a lethal yellowing-type disease (LYD) of coconut (Cocos nucifera L.) in Mozambique. Int. J. Syst. Evol. Microbiol. 64: 1890-1899.

Hoat, T. X., Bon, N. G., Quan, M. V., Hien, V. D., Thanh, N. D., and Dickinson, M. 2012. Detection and molecular characterization of sugarcane grassy shoot phytoplasma in Vietnam. Phytoparasitica 40:351-359.

Hodgetts, J., Boonham, N., Mumford, R., Harrison, N., and Dickinson, M. 2008. Phytoplasma phylogenetics based on analysis of secA and 23S rRNA gene sequences for improved resolution of candidate species of 'Candidatus Phytoplasma'. Int. J. Syst. Evol. Microbiol. 58:1826-1837.

Hogenhout, S. A., Oshima, K., Ammar, E. D., Kakizawa, S., Kingdom, H. N., and Namba, S. 2008. Phytoplasmas: Bacteria that manipulate plants and insects. Mol. Plant Pathol. 9:403-423.

IRPCM Phytoplasma/Spiroplasma Working Team-Phytoplasma taxonomy group. 2004. 'Candidatus Phytoplasma', a taxon for the wall-less, non-helical prokaryotes that colonize plant phloem and insects. Int. J. Syst. Evol. Microbiol. 54:1243-1255.

Jones, P., Devonshire, B. J., Holman, T. J., and Ajanga, S. 2004. Napier grass stunt: A new disease associated with a $16 \mathrm{SrXI}$ group phytoplasma in Kenya. Plant Pathol. 53:519.

Jung, H.-Y., Sawayanagi, T., Wongkaew, P., Kakizawa, S., Nishigawa, H., Wei, W., Oshima, K., Miyata, S.-I., Ugaki, M., Hibi, T., and Namba, S. 2003. 'Candidatus Phytoplasma oryzae' a novel phytoplasma taxon associated with rice yellow dwarf disease. Int. J. Syst. Evol. Microbiol. 53:1925-1929.

Kanatiwela-de Silva, C., Damayanthi, M., de Silva, R., Dickinson, M., de Silva, N., and Udagama, P. 2015. Molecular and scanning electron microscopic proof of phytoplasma associated with areca palm yellow leaf disease in Sri Lanka. Plant Dis. 99:1641.

Kube, M., Schneider, B., Kuhl, H., Dandekar, T., Heitmann, K., Migdoll, A. M., Reinhardt, R., and Seemüller, E. 2008. The linear chromosome of the plantpathogenic mycoplasma 'Candidatus Phytoplasma mali'. BMC Genomics 9: 306.

Kumar, S., Tiwari, A. K., Holkar, S. K., Duttamajumder, S. K., and Rao, G. P. 2015. Characterization of a 16SrI-B phytoplasma associated with sugarcane leaf yellows disease in India. Sugar Tech 17:156-161.

Kumarasinghe, N. C., and Jones, P. 2001. Identification of white leaf disease of sugarcane in Sri Lanka. Sugar Tech 3:55-58.

Lee, I.-M., Gundersen-Rindal, D. E., and Bertaccini, A. 1998. Phytoplasma: Ecology and genomic diversity. Phytopathology 88:1359-1366.

Lee, I.-M., Hammond, R. W., Davis, R. E., and Gundersen, D. E. 1993. Universal amplification and analysis of pathogen $16 \mathrm{~S}$ rDNA for classification and identification of mycoplasmalike organisms. Phytopathology 83:834-842.

Lorenz, K. H., Schneider, B., Ahrens, U., and Seemüller, E. 1995. Detection of the apple proliferation and pear decline phytoplasmas by PCR amplification of ribosomal and nonribosomal DNA. Phytopathology 85:771-776.

Makarova, O., Contaldo, N., Paltrinieri, S., Kawube, G., Bertaccini, A., and Nicolaisen, M. 2012. DNA barcoding for identification of 'Candidatus Phytoplasmas' using a fragment of the elongation factor Tu gene. PLoS One 7:e52092.

Manimekalai, R., Soumya, V. P., Sathish Kumar, R., Selvarajan, R., Reddy, K., Thomas, G. V., Sasikala, M., Rajeev, G., and Baranwal, V. K. 2010. Molecular detection of a $16 \mathrm{SrXI}$ group phytoplasma associated with root (wilt) disease of coconut (Cocos nucifera L.) in India. Plant Dis. 94:636.

Marcone, C. 2002. Phytoplasma diseases of sugarcane. Sugar Tech 4:79-85.
Martens, M., Dawyndt, P., Coopman, R., Gillis, M., De Vos, P., and Willems, A 2008. Advantages of multilocus sequence analysis for taxonomic studies: A case study using 10 housekeeping genes in the genus Ensifer (including former Sinorhizobium). Int. J. Syst. Evol. Microbiol. 58:200-214.

Nasare, K., and Yadav, A. 2007. Molecular and symptom analysis reveal the presence of new phytoplasmas associated with sugarcane grassy shoot disease in India. Plant Dis. 91:1413-1418.

Nejat, N., Sijama, K., Abdullahb, S. N. A., Vadamalaia, G., and Dickinson, M. 2009. Phytoplasmas associated with disease of coconut in Malaysia: Phylogenetic groups and host plant species. Plant Pathol. 58:1152-1160.

Obura, E., Midega, C. A. O., Masiga, D., Pickett, J. A., Hassan, M., Koji, S., and Khan, Z. R. 2009. Recilia banda Kramer (Hemiptera: Cicadellidae), a vector of Napier stunt phytoplasma in Kenya. Naturwissenschaften 96:1169-1176.

Oshima, K., Kakizawa, S., Nishigawa, H., Jung, H.-Y., Wei, W., Suzuki, S., Arashida, R., Nakata, D., Miyata, S., Ugaki, M., and Namba, S. 2004 Reductive evolution suggested from the complete genome sequence of a plant pathogenic phytoplasma. Nat. Genet. 36:27-29.

Perera, L., Meegaskubura, M. K., Wijesekara, H. R. T., Fernando, W. B. S., and Dickinson, M. J. 2012. A phytoplasma is associated with the Weligama coconut leaf wilt disease in Sri Lanka. J. Plant Pathol. 94:205-209.

Ramaswamy, M., Nair, S., Soumya, V. P., and Thomas, G. V. 2013. Phylogenetic analysis identifies a 'Candidatus Phytoplasma oryzae'-related strain associated with yellow leaf disease of areca palm (Areca catechu L.) in India. Int. J. Syst. Evol. Microbiol. 63:1376-1382.

Schneider, B., Seemüller, E., Smart, C. D., and Kikpatrick, B. C. 1995. Phylogenetic classification of plant pathogenic mycoplasma-like organisms or phytoplasmas Pages 369-380 in: Molecular and Diagnostic Procedures in Mycoplasmology. S. Razin and J. G. Tully, eds. Academic Press, San Diego, CA

Schoch, C. L., Shoemaker, R. A., Seifert, K. A., Hambleton, S., Spatafora, J. W., and Crous, P. W. 2006. A multigene phylogeny of the Dothideomycetes using four nuclear loci. Mycologia 98:1041-1052.

Soufi, Z., Sakuanrungsirikul, S., Wongwarat, T., Hamarn, T., Srisink, S., and Komor, E. 2013. Sugarcane yellow leaf symptomatic plants in Thailand are infected by white leaf phytoplasma, not by leaf yellows phytoplasma. Australas. Plant Pathol. 42:723-729.

Tamura, K., Stecher, G., Paterson, D., Filipski, A., and Kumar, S. 2013. Molecular evolutionary genetics analysis version 6.0. Mol. Biol. Evol. 30:2725-2729.

Thompson, J. D., Higgins, D. G., and Gibson, T. J. 1994. CLUSTAL W: Improving the sensitivity of progressive multiple sequence alignment through sequence weighting, positions-specific gap penalties and weight matrix choice. Nucleic Acids Res. 22:4673-4680.

Tomlinson, J. A., Dickinson, M., and Boonham, N. 2010. Rapid detection of Phytophthora ramorum and $P$. kenoviae by two-minute DNA extraction followed by isothermal amplification and amplicon detection by generic lateral flow device. Phytopathology 100:143-149.

Tran-Nguyen, L., Blanche, K. R., Egan, B., and Gibb, K. S. 2000. Diversity of phytoplasmas in northern Australian sugarcane and other grasses. Plant Pathol. 49:666-679.

Tran-Nguyen, L. T. T., Kube, M., Schneider, B., Reinhardt, R., and Gibb, K. S 2008. Comparative genome analysis of 'Candidatus Phytoplasma australiense' (subgroup tuf-Australia I: rp-A) and ' $\mathrm{Ca}$. Phytoplasma asteris' strains OY-M and AY-WB. J. Bacteriol. 190:3979-3991.

Viswanathan, R., Chinaraka, C., Karuppaiah, R., Kumar, V. G., Rooba, J. J., and Malathi, P. 2011. Genetic diversity of sugarcane grassy shoot (SCGS) phytoplasmas causing grassy shoot disease in India. Sugar Tech 13:220-228.

Wei, W., Davis, R. E., Lee, I.-M., and Zhao, Y. 2007. Computer-simulated RFLP analysis of $16 \mathrm{~S}$ rRNA genes: Identification of ten new phytoplasma groups. Int. J. Syst. Evol. Microbiol. 57:1855-1867.

Wongkaew, P., Hanboonsong, Y., Sirithorn, P., Choosai, C., Boonkrong, S. Tinnangwattana, T., Kitchareonpanya, B., and Damak, S. 1997. Differentiation of phytoplasmas associated with sugarcane and gramineous weed white leaf disease and sugarcane grassy shoot disease by RFLP and sequencing. Theor. Appl. Genet. 95:660-663 